\title{
Response to the "Comment on the New DGGG AWMF S3-Guideline on Hysterectomy, or a Plea for LAVH as the Gold Standard for Total Hysterectomy Procedures" by Prof. Rudy Leon De Wilde
}

\author{
Stellungnahme zum „Kommentar zu der neuen DGGG-AWMF-S3-Leitlinie ,Hysterektomie‘ oder \\ ein Plädoyer für die LAVH als Goldstandard bei der totalen Hysterektomie“ von Prof. Rudy Leon de Wilde
}

Author

Affiliations
K. J. Neis ${ }^{1,2}$

${ }^{1}$ Klinik für Frauenheilkunde, Geburtshilfe und Reproduktionsmedizin der Universitätsklinik des Saarlandes, Homburg

${ }^{2}$ Frauenärzte am Staden, Saarbrücken
Deutsche Version unter: www.thieme-connect.de/ ejournals/gebfra
Bibliography

Dol http://dx.doi.org/

10.1055/s-0042-104694

Geburtsh Frauenheilk 2016; 76:

367-368 @ Georg Thieme

Verlag KG Stuttgart · New York .

ISSN 0016-5751

\section{Correspondence}

Prof. Dr. med. Klaus J. Neis

Frauenärzte am Staden

Bismarckstraße 39-41

66121 Saarbrücken

kjneis@gyn-saar.de
I would like to thank Prof. De Wilde for his comment. We particularly appreciate his congratulatory remarks about our work and I would like to take this opportunity to pass on his compliments to all the other members of the Guideline Development Group who voluntarily dedicated so much of their time to bring the task to fruition. I would also like to thank Prof. Kreienberg for suggesting the guideline and thank the board of the DGGG for their decision to ask an external panel to review the guideline (which had already been completed at the end of 2012) and - because of the significance of the guideline for healthcare policies - to commission an evidence report. The fact that we were able to recruit Dr. M. Nothacker with her extensive knowledge of both methodology and gynecology can only be described as a stroke of luck.

There is a general consensus worldwide that, where possible, preference should be given to vaginal hysterectomies over abdominal hysterectomies. If this is not possible, one of 3 laparoscopic methods should be used to avoid having to perform an abdominal hysterectomy [1-3].

In Germany, Austria and Switzerland, this problem was well on the way to being resolved even as work on the guideline was still underway. While in most countries the percentage of abdominal hysterectomies performed in 2012 was still over $50 \%$, the figure for Austria was just $28.0 \%$ [4] while for Switzerland it stood at 23.9\% [5] and in Germany it was a mere $15.7 \%$ [6]. The latter figure is the lowest rate for abdominal hysterectomies ever reported as a national statistic for any country worldwide.

The fact that in German-speaking countries this goal was already achieved in 2012, in other words, 3 years before the guideline was issued, and that it was achieved without external pressure and was the result of the commitment of gynecologic surgeons was reflected in the development process of the guideline. We did not have to describe what needed to be done; we only had to report on what we had already implemented. We launched the first structured observational study on laparoscopic hysterectomy in Germany in 1990 , that is, only one year after $\mathrm{H}$. Reich published his first TLH [7]. In the hospital I headed when the study was first initiated, we also took the decision to carry out LAVH [8]. The main reason for our decision at the time was the comparatively low rate of complications following LAVH compared to TLH. But because cervical stump cancer was then still a hotly disputed issue, it was not possible to make the case for LASH in Germany at the time [9].

Following the introduction of LAVH the percentage of abdominal hysterectomies dropped continually within the space of just 1.5 years to $6-7 \%$ [10].

Later, once all 3 laparoscopic surgical hysterectomy techniques were fully developed, other centers in Germany took the same path, although they primarily focused on LASH or TLH.

Currently, purely vaginal hysterectomy procedures are considered the method of choice worldwide, as they combine the benefits of rapid convalescence with a low rate of complications and shorter operating times [11]. Moreover, vaginal hysterectomy procedures are the most cost-effective type of surgery; in the USA it is the only one which does not negatively affect hospital budgets $[12,13]$.

From a subjective point of view and based on my personal clinical and scientific development I, like Prof. De Wilde, would still favor LAVH over other laparoscopic surgical techniques, but I do believe that there are enough arguments highlighting the equivalent benefits of LASH or TLH, both of which are also associated with very low rates of complications when performed by experienced surgeons [14]. To ensure that all women receive optimal care and that every woman everywhere is offered the surgical method most appropriate 
to her circumstances, the full range of hysterectomy procedures must be mastered and taught across the whole country. That is the only way the above-mentioned, globally unique outcomes were achieved.

The largest group of authors involved in compilation of the guideline were from the Gynecologic Endoscopy Working Group (AGE e.V.). This was because the Working Group has not only focused on developing minimally invasive hysterectomy procedures but is also working to develop alternative organ-preserving surgical procedures in Germany and Europe and has significantly contributed to the dissemination of these techniques. This ensured that the guideline did not only focus on hysterectomy procedures but also included detailed descriptions of alternative procedures and carefully reviewed the evidence for both types of approaches.

Algorithms were developed to provide support to patients and physicians in their search for the optimal approach in each individual case; the algorithms addressed the most important indications: myomatous uterus, bleeding disorders and endometriosis. These algorithms allow patients to see at a glance how many different possibilities to alleviate her symptoms there are and should enable her, together with her doctor, to find the approach which is most suitable for her in her current circumstances. The efforts taken to ensure that patients are actively involved in the decision-making process run like a common thread through the guideline.

In the last 10-15 years, the number of hysterectomies has continually dropped both in Germany and worldwide. It appears that the alternative organ-preserving methods we developed and disseminated are beginning to take hold. But this still needs to be substantiated. In 2013 hysterectomy procedures were removed from quality assurance standards because the endpoints had been met. A fresh approach will now be necessary which will set out cross-sectoral quality standards for hysterectomy procedures including alternative procedures.

The guideline presented here is a description of what is currently useful and possible; it is, so to speak, a prelude which aims to continue building on what has already been achieved to the benefit of our patients. But - and here I believe that I speak for all the members of our Guideline Development Group - as anyone who is constantly looking for further opportunities to optimize treatment knows, we still have a lot of work to do. We are helped on our way not merely by the good wishes but also by the active support we receive from our colleagues who are also deeply in- volved in the issue, as is borne out by the reflections of Prof. De Wilde, whom we - along with all our other colleagues - are happy to take along with us on the road ahead.

\section{Conflict of Interest}

Klaus J. Neis is scientific director of the European Training Center for Gynecologic Endoscopy and Surgery (ETC), the ETC is supported by Karl Storz and Erbe.

\section{References}

1 Aarts JW, Nieboer TE, Johnson $N$ et al. Surgical approach to hysterectomy for benign gynaecological disease. Cochrane Database Syst Rev 2015; 8: CD003677

2 National Institute for Health and Clinical Excellence. Interventional procedure overview of laparoscopic techniques for hysterectomy. Online: http://www.nice.org.uk/guidance/ipg239/evidence/overview309106333; last access: 11.01.2016

3 ACOG Committee Opinion No.444: choosing the route of hysterectomy for benign disease. Obstet Gynecol 2009; 114: 1156-1158

4 Gesundheit Austria. Online: http://www.statistik.at/web_de/ statistiken/menschen_und_gesellschaft/gesundheit/stationaere_ aufenthalte/medizinische_leistungen/index.html; last access: 11.01.2016

5 ASF. ASF. Online: http://www.sevisa.ch/; last access: 11.01.2016

6 AQUA - Institut für angewandte Qualitätsförderung und Forschung im Gesundheitswesen $\mathrm{GmbH}$. Bundesauswertung zum Verfassungsjahr 2012. 15/1 Gynäkologische Operationen 2013. Online: https://www. sqg.de/downloads/Bundesauswertungen/2012/bu_Gesamt_15N1GYN-OP_2012.pdf; last access: 11.01.2016

7 Reich $\mathrm{H}$. Total laparoscopic hysterectomy: indications, techniques and outcomes. Curr Opin Obstet Gynecol 2007; 19: 337-344

8 Neis KJ, Ulrich K, Zeilmann W et al. Die laparoskopisch-assistierte vaginale Hysterektomie. Der Frauenarzt 1993; 34: 1091-1096

9 Semm K. Personal communication 1991

10 Brandner P, Neis KJ. [The significance of laparoscopically-assisted vaginal hysterectomy-LAVH]. Zentralbl Gynakol 1995; 117: 620-624

11 Nieboer TE, Johnson N, Lethaby A et al. Surgical approach to hysterectomy for benign gynaecological disease. Cochrane Database Syst Rev 2009; 3: CD003677

12 Woelk JL, Borah BJ, Trabuco EC et al. Cost differences among robotic, vaginal, and abdominal hysterectomy. Obstet Gynecol 2014; 123 (2 Pt 1): $255-262$

13 Lonnerfors C, Reynisson P, Persson J. A randomized trial comparing vaginal and laparoscopic hysterectomy vs. robot-assisted hysterectomy. J Minim Invasive Gynecol 2015; 22: 78-86

14 Donnez J, Nisolle M. Laparoscopic supracervical (subtotal) hysterectomy (LASH). J Gynecol Surg 1993; 9: 91-94 